\section{Distribution of Horseradish Peroxidase Activity in Horseradish Plants}

\author{
Mosbah M. Kushad ${ }^{1}$, Mohammed Guidera, and Anthony D. Bratsch \\ 279 ERML, 1201 West Gregory Drive, Department of Natural Resources and \\ Environmental Sciences, University of Illinois, Urbana, IL 61801
}

Additional index words. Aromoracia rusticana, decontamination, enzyme, health, protein

\begin{abstract}
Thirty horseradish (Armoracia rusticana Gaertn., Mey., \& Scherb.) cultivars from eight countries in Europe and North America and from advanced lines developed at the Univ. of Illinois were evaluated for horseradish peroxidase (HRP; electrical conductivity 1.11 .1 .7 , donor : hydrogen peroxide oxido-reductase) activity. Nearly $86 \%$ of the activity was present in the taproot and lateral roots and $14 \%$ in the leaf petiole, but there was no activity in the leaf blade. The 30 cultivars were divided into three groups with high (eight cultivars), medium (13 cultivars), and low (nine cultivars) activities [11.58 to 16.97, 7.19 to 9.79 , and 2.88 to $6.91 \mu \mathrm{mol} \cdot \mathrm{min}^{-1} \cdot \mathrm{g}^{-1}$ fresh weight $(\mathrm{FW})$, respectively]. The cultivars with the highest activity were 819-A from the Illinois and 810-A from Switzerland with 16.97 and $16.67 \mu \mathrm{mol} \cdot \mathrm{min}^{-1} \cdot \mathrm{g}^{-1} \mathrm{FW}$, respectively. The cultivar with the lowest HRP activity was 244 -A from the United States with $2.88 \mu \mathrm{mol} \cdot \mathrm{min}^{-1} \cdot \mathrm{g}^{-1} \mathrm{FW}$. Cultivar 819-A also had the highest protein concentration $\left(4.92 \mathrm{mg}^{-1} \mathrm{~g}^{-1} \mathrm{FW}\right)$. When HRP activity was expressed per milligrams of protein, cultivar 167-A, also known as 'Bohemian', had the highest activity and cultivar 244 -A had the lowest $\left(5.35\right.$ and $0.83 \mu \mathrm{mol} \cdot \mathrm{min}^{-1} \cdot \mathrm{mg}^{-1}$ protein, respectively).
\end{abstract}

Horseradish is a perennial rootcrop of the Cruciferae family. It is one of the oldest known condiments, valued for its extremely pungent, fleshy roots (Rhodes et al., 1965). Approximately $60 \%$ of the 8000 tons of horseradish produced annually in the United States is grown in Illinois on deep and fertile loess-originated soil near the Mississippi River east of Saint Louis (Peck et al., 1969; Rhodes et al., 1965). The bulk of the horseradish is processed into a paste and used as a food additive. The pungency of horseradish is due to the hydrolysis of sinigrin by a complex enzyme called myrosinase into allylisothiocyanate, butylthiocyanate, glucose, and sulfate (Ohtsuru and Kawatani, 1979).

Horseradish production in the United States has not changed significantly in the last several decades. Recently identified uses for horseradish products, however, offer growers new opportunities to expand production. Horseradish roots are rich in horseradish peroxidase. About $82 \%$ of the commercially available enzyme is used in kits to test for levels of glucose and cholesterol in blood (Krel, 1991). The enzyme is also an invaluable tool in life sciences (Ryan et al., 1994), and has been used as an indicator in oxidase-based immunoassays (Tijssen, 1985), in estimation of the level of other enzymes (Akhavan et al., 1994), in cytochemistry (Oliver et al., 1984), and in preparation of DNA probes (Cercek et al.,

\footnotetext{
Received for publication 11 May 1998. Accepted for publication 11 Aug. 1998. This work was supported in part through funding from the Illinois Council for Agricultural Research (C-FAR 97I-60) and Illinois Horseradish Growers Association. The cost of publishing this paper was defrayed in part by the payment of page charges. Under postal regulations, this paper therefore must be hereby marked advertisement solely to indicate this fact.

${ }^{1}$ To whom reprint requests should be addressed.
}

Table 1. Origins of the 30 cultivars of horseradish tested.

${ }^{2}$ Common name: "SASS" or "TH-107."

y'Common name: "Big Top Western."

'Common name: "Bohemian."

"Exact origin in the United States is not known. no studies on the activity of HRP in different varieties of horseradish or on the
1995). Peroxidase is also important in industrial (Harazono et al., 1996), degradation of wood pulp into fuel (Macek et al., 1993), and rematic amines, phenols, and nitrate, from industrial wastewater (Dec and Bollag, 1994; In 1991, world production of horseradish 2010 (Krel, 1991). There are presently Co., St.Louis; ICN Pharmaceuticals Inc., tract the enzyme from a few commercial cultivars selected primarily for their paste quality. However, to our knowledge, there have distribution of the enzyme in the horseradish plant. The objective of this study was to provide preliminary evaluation of HRP activity in 30 horseradish cultivars and advanced selections, with the objective of optimizing HRP production.

\section{Materials and Methods}

The 30 cultivars selected for this study are part of a collection housed at the Univ. of Illinois Urbana-Champaign campus; their origins are listed in Table 1. Morphological characteristics of six of these cultivars (104-A, 113-A, 125-A, 167-A, 196-A, and 777-A), as well as 45 others not listed in this study, have been described by Rhodes et al. $(1965,1969)$. Plants were grown in a completely randomized block design of four replicates per cultivar. To determine the distribution of HRP activity in various parts of the horseradish plant, composite samples of $50 \mathrm{~g}$ fresh weight (FW) from leaf blades, leaf petioles, taproot, or lateral roots of five cultivars (104-A, 125-A, 777-A, 819-A, and 1573) were assayed separately. Leaf blade and petiole samples were collected from fully developed leaves on 11 July 1996, while taproot and lateral root samples were collected at commercial harvest time on 7 Oct. 1996 and assayed for HRP activity according to a procedure outlined below.

Based on the results from the distribution study, the activity in the 30 cultivars and advanced selections was determined using a sample composed of the taproot and lateral roots in equal proportions. One plant from each of four replicates of the 30 cultivars was harvested on 7 Oct. 1996, placed in a plastic bag, top iced, and transported into the laboratory. Within $30 \mathrm{~min}$ of harvest, roots were cleaned with distilled water and $30 \mathrm{~g} \mathrm{FW}$ was collected from the middle portion of the tap$\operatorname{root}(15 \mathrm{~g})$ and lateral roots $(15 \mathrm{~g})$, combined, and ground into fine powder under liquid nitrogen with a mortar and pestle. The powdered tissue was suspended in $45 \mathrm{~mL}$ of extraction buffer consisting of $15 \mathrm{~mm}$ sodium phosphate (pH 6.0), 10\% triton $\mathrm{X}-100$, and $3 \%$ (w/v) polyvinylpoly-pyrrolidone and homogenized with a Polytron homogenizer (Brinkman Inst., Westbury, N.Y.) set at a speed of 4 . The homogenate was centrifuged for $30 \mathrm{~min}$ at

\begin{tabular}{ll}
\hline \hline Cultivar number & \multicolumn{1}{c}{ Origin } \\
\hline 51-A, 53-A, 502-A, 532-A, 789-A, 813-A, 819-A, 1236, 1724-3, 1573 & Illinois, U.S.A. \\
196-A & Canada \\
856-A & Czechoslovakia \\
777-A & Hungary \\
764-A & Poland \\
104-A, 106-A, 113-A & Russia \\
$807-A, 810-A, 811-A$, 863-A & Switzerland \\
167-A $, 204-A^{\mathrm{x}}, 244-\mathrm{A}$ & U.S.A." \\
125-A, 239-A, 493-A & Wisconsin, U.S.A \\
$753-\mathrm{A}$ & Yugoslavia \\
$1573,1609,1717$ & Unknown \\
\hline
\end{tabular}


$27,000 g_{\mathrm{n}}$ and $4{ }^{\circ} \mathrm{C}$. The supernatant was collected, dialyzed overnight against the same buffer to remove low molecular weight compounds, and stored at $-70{ }^{\circ} \mathrm{C}$ for further determination of HRP activity. Due to their high HRP activity, extracts from the root tissues were diluted (1:10) with buffer prior to assay.

Horseradish peroxidase activity was determined spectrophotometrically based on the oxidation of guaiacol (o-methylphenol) in the presence of $\mathrm{H}_{2} \mathrm{O}_{2}$ (Reuveni et al., 1992). The reaction mixture consisted of $1 \mathrm{mM} \mathrm{H}_{2} \mathrm{O}_{2}, 0.1$ mM guaiacol (o-methylphenol), $15 \mathrm{~mm}$ potassium phosphate ( $\mathrm{pH} 6.0$ ), and $20 \mu \mathrm{L}$ enzyme extract in a total volume of $1 \mathrm{~mL}$. The mixture was placed in a $1-\mathrm{mL}$ quartz cuvette and the optical density was recorded in 1-min intervals for 3 min using a Shimadzu UV160U spectrophotometer (Shimadzu Corp., Kyoto, Japan) set at $470 \mathrm{~nm}$. Horseradish peroxidase activity was determined by measuring the difference in optical density between reactions with and without guaiacol as a function of time (the extinction coefficient of guaiacol is $\mathbf{2 5 . 5}$ $\left.\mathrm{mm}^{-1} \cdot \mathrm{cm}^{-1}\right)$. Changes in optical density were linear during the first $3 \mathrm{~min}$ of the reaction.

Activity was expressed in $\mu \mathrm{mol} \cdot \mathrm{min}^{-1} \cdot \mathrm{g}^{-1}$ FW and also as specific activity in $\mu \mathrm{mol}$. $\mathrm{min}^{-1} \cdot \mathrm{mg}^{-1}$ protein. Protein concentration was determined according to Bradford (1976). Data were subjected to analysis of variance (ANOVA) using the SAS statistical program (SAS Institute, 1985) and differences among treatment means were compared using the least significant difference (LSD) mean separation test.

\section{Results and Discussion}

Peroxidase activity differed in the different parts of the plant, with $49 \%$ of the total activity in the taproots (Table 2), and $37 \%$ in the lateral roots. Activity in the leaf was very low; only $14 \%$ of the total activity occurred in the leaf petiole and no activity was detected in the leaf blade (Table 2). Our results are in agreement with those of Kawaoka et al. (1992), who examined expression and promoter activities of genes for horseradish peroxidase isozymes and reported expression of one gene group (prxCla and prxC1b) in the leaf petiole, two genes (prxC2 and prxC3) were expressed in the root, and no peroxidase genes in the leaf. Dunleavy and Urs (1978) examined the distribution of peroxidase in soybean leaves and roots during plant development, and reported that activity in the roots was between 4- and 17 -fold that in the leaves. They found no

Table 2. Distribution of peroxidase activity in horseradish plant parts.

\begin{tabular}{lc}
\hline \hline Plant parts & Peroxidase activity (\% of total) \\
\hline Taproot & 48.8 \\
Lateral roots & 37.3 \\
Leaf petiole & 13.9 \\
Leaf blade & 0.0 \\
$P>F$ & $* * *$ \\
LSD $_{0.05}$ & 9.6 \\
\hline
\end{tabular}

${ }^{* * *}$ Significant at $P<0.001$. Peroxidase activity values are from tissues pooled from five different cultivars (104-A, 125-A, 777-A, 819-A, and 1573). correlation between peroxidase activity in the roots vs. the leaves, suggesting that the enzyme activities in the two tissues are independently regulated. This lack of activity in the leaves could be an economic setback to the growers because leaves constitute $\approx 20 \%$ of the total plant FW (data not shown).

Activity in the roots also differed among cultivars (Table 3 ). The cultivars 819-A and 810-A contained the highest activity (16.97 and $16.67 \mu \mathrm{mol} \cdot \mathrm{min}^{-1} \cdot \mathrm{g}^{-1} \mathrm{FW}$, respectively) and 244-A contained the lowest activity (2.88 $\mu \mathrm{mol} \cdot \mathrm{min}^{-1} \cdot \mathrm{g}^{-1} \mathrm{FW}$ ).

The cultivar 167-A contained the highest activity on a unit protein basis $(5.35 \mu \mathrm{mol}$. $\mathrm{min}^{-1} \cdot \mathrm{mg}^{-1}$ protein), followed by 764-A, 1724-3, and 863-A. Activity in 167-A was similar to that in horseradish callus K6DIO, but about one-seventh of that in $\mathrm{K} 6 / 2+\mathrm{K}$ (Macek et al.,1993). Cultivar 244-A also had the lowest specific activity $\left(0.83 \mu \mathrm{mol} \cdot \mathrm{min}^{-1}\right.$ $\cdot \mathrm{mg}^{-1}$ protein). The remaining cultivars ranged in activity from 1.09 to $3.96 \mu \mathrm{mol} \cdot \mathrm{min}^{-1} \cdot \mathrm{mg}^{-1}$ protein. Protein concentrations were also variable among the cultivars (Table 2). Cultivars 819-A and 810-A, which had the highest HRP activity per gram $\mathrm{FW}$, also had higher protein concentrations than did other cultivars (4.92 and $4.45 \mathrm{mg} \cdot \mathrm{g}^{-1} \mathrm{FW}$, respectively). Cultivar $819-\mathrm{A}$ is a cross between 72-A and 196-A, a Canadian selection (Table 1). Cultivar 1573, which is the most widely grown cultivar in Illinois because of its relatively high yield $\approx 8$ $\mathrm{Mg} \cdot \mathrm{ha}^{-1}$ ) and good processing quality, contained $\approx 24 \%$ less HRP activity per gram FW and $\approx 25 \%$ less protein than did cultivar 819 -A. We are in the process of comparing yield potential of cultivars 819-A vs. 1573 .

Substantial peroxidase activity has also been reported in peanut, tobacco, soybean, and cultured potato cells (Buttery and Buzzell, 1968; Cairns et al., 1980; Lobarzewski and van Huystee, 1982). Buttery and Buzzell (1968) evaluated peroxidase activity in seed coats of 28 soybean cultivars, which could be classified into groups with either high or low activity. Peroxidase activity in the former was as much as 78 -fold as high as that in the latter. Peroxidase activity in the highest soybean seed group is $\approx 1 \%$ of that in horseradish cultivar 167-A (Table 3).

Dunleavy and Urs (1978) evaluated roots of 24 soybean cultivars and found a maximum difference among cultivars of 19 -fold in young plants vs. 2.5-fold in mature plants. However, we found no significant difference in HRP

Table 3. Total horseradish peroxidase activity and protein concentration in roots of 30 cultivars of horseradish.

\begin{tabular}{|c|c|c|c|}
\hline \multirow{2}{*}{$\begin{array}{l}\text { Illinois cultivar } \\
\text { number }\end{array}$} & \multicolumn{2}{|c|}{ Horseradish peroxidase activity } & \multirow{2}{*}{$\frac{\text { Protein concentration }}{\mathrm{mg} \cdot \mathrm{g}^{-1} \mathrm{FW}}$} \\
\hline & $\mu \mathrm{mol} \cdot \mathrm{min}^{-1} \cdot \mathrm{g}^{-1} \mathrm{FW}^{2}$ & $\mu \mathrm{mol} \cdot \mathrm{min}^{-1} \cdot \mathrm{mg}^{-1}$ protein & \\
\hline \multicolumn{4}{|c|}{ High activity } \\
\hline 819-A & 16.97 & 3.45 & 4.92 \\
\hline 810-A & 16.67 & 3.75 & 4.45 \\
\hline $113-\mathrm{A}$ & 13.44 & 3.77 & 3.56 \\
\hline $1724-3$ & 12.51 & 4.72 & 2.65 \\
\hline $493-\mathrm{A}$ & 12.47 & 2.90 & 4.30 \\
\hline $125-\mathrm{A}$ & 12.18 & 3.46 & 3.52 \\
\hline 764-A & 12.16 & 4.80 & 2.53 \\
\hline 777-A & 11.58 & 2.81 & 4.12 \\
\hline Mean & $\overline{13.50}$ & $\overline{3.71}$ & $\overline{3.76}$ \\
\hline \multicolumn{4}{|c|}{ Medium activity } \\
\hline 1573 & 9.79 & 2.64 & 3.71 \\
\hline 204-A & 9.51 & 2.19 & 4.35 \\
\hline $106-\mathrm{A}$ & 9.50 & 2.18 & 4.35 \\
\hline 104-A & 8.78 & 2.27 & 3.87 \\
\hline $502-\mathrm{A}$ & 8.73 & 2.29 & 3.81 \\
\hline $167-\mathrm{A}$ & 8.67 & 5.35 & 1.62 \\
\hline 813-A & 8.61 & 3.32 & 2.59 \\
\hline 753-A & 8.47 & 2.31 & 3.66 \\
\hline 1717 & 8.40 & 3.05 & 2.75 \\
\hline 1609 & 7.78 & 2.98 & 2.61 \\
\hline $856-\mathrm{A}$ & 7.77 & 2.64 & 2.94 \\
\hline $239-A$ & 7.38 & 1.67 & 4.42 \\
\hline 789-A & 7.19 & 2.47 & 2.91 \\
\hline Mean & 8.51 & $\overline{2.72}$ & $\overline{3.35}$ \\
\hline \multicolumn{4}{|c|}{ Low activity } \\
\hline 807-A & 6.91 & 1.96 & 3.53 \\
\hline 532-A & 6.58 & 3.96 & 1.66 \\
\hline $811-\mathrm{A}$ & 6.50 & 1.92 & 3.38 \\
\hline $51-\mathrm{A}$ & 5.51 & 1.44 & 3.83 \\
\hline 1236 & 5.17 & 1.09 & 4.73 \\
\hline 196-A & 5.08 & 1.72 & 2.96 \\
\hline $53-\mathrm{A}$ & 4.86 & 1.64 & 2.96 \\
\hline 863-A & 4.72 & 4.03 & 1.17 \\
\hline 244-A & 2.88 & 0.83 & 3.44 \\
\hline Mean & $\overline{5.36}$ & $\overline{2.07}$ & $\overline{3.07}$ \\
\hline$P>F$ & $* * *$ & $* * *$ & $* * *$ \\
\hline $\mathrm{LSD}_{0.05}$ & 2.54 & 0.98 & 0.80 \\
\hline
\end{tabular}

${ }^{2} \mathrm{FW}=$ fresh weight.

${ }^{* * *}$ Significant at $P<0.001$. 
activity between roots harvested in Oct. 1996 vs. May 1997 (data not shown), suggesting that root age is not a limiting factor in horseradish.

In addition to the roots, HRP has also been extracted from horseradish callus (Lotmani and Rabier, 1988), cell suspension, and hairy root cultures (Macek et al., 1993; Parkinson et al., 1993). Macek et al. (1993) reported that HRP activity was $\approx 4$-fold higher in the supernatant of suspension culture as in cells or callus and 30-fold as high as in root tissue. However, HRP from suspension cultures consists of four isozymes, while that from intact roots consists of seven. Also, $\mathrm{pH}$ and temperature optima of HRP from cell cultures and intact roots differed (Macek et al., 1993; Parkinson et al., 1990). Our assay procedure measures total peroxidase activity of all isozymes.

In summary, significant differences in HRP activity were observed among the 30 horseradish cultivars. Eight cultivars showed high activity, 13 showed medium activity, and nine showed low activity. Horseradish peroxidase activity was present in the roots and leaf petiole, but no activity was detected in the leaf blade.

\section{Literature Cited}

Akhavan-Tafti,H.,A.Schaap,Z. Arghavani,R.DeSilva, R. Eickholt, R. Handley, B. Schoenfelener, K. Sugioka, and Y. Sugioka. 1994. CCD camera imagery for the chemiluminescent detection of enzymes using new utrasensitive reagents. J. Biolumin. Chemilumin. 9:155-164.

Bradford, M.M. 1976. A rapid and sensitive method for the quantitation of microgram quantities of protein utilizing the principle of protein-dye binding. Anal. Biochem. 72:248254.

Buttery, B. and R. Buzzell. 1968. Peroxidase activity in seed of soybean varieties. Crop Sci. 8:722725 .
Cercek, B., K. Roby, and M. Siaw. 1995. A reagent for both visualization and chemiluminescence detection of horseradish peroxidase-tagged DNA probes. Anal. Biochem. 232:143-144.

Cairns, E., R.R. Van Huystee, and W. Cairns. 1980 Peanut and horseradish peroxidase isozymes. Intraspecific and interspecific immunological relatedness. Physiol. Plant. 49:78-82.

Dec, J. and J.M. Bollag. 1994. Use of plant material for the decontamination of water polluted with phenols. Biotech. Bioeng. 44:1132-1139.

Dunleavy, J.M. and N.V.R. Urs. 1978. Peroxidase activity in roots and leaves of soybeans. Crop Sci. 18:104-108.

Harazono, K., R. Kondo, and K. Sakai. 1996. Bleaching of hardwood kraft pulp with manganese peroxidase from Phanerochaete soridida YK-624 without addition of $\mathrm{MnSO}_{4}$. Appl Environ. Microbiol. 62:913-917.

Kawaoka, A., S. Sato, K. Nakahara, N. Matsushima, N. Okada, A. Shinmyo, and M. Takano. 1992. Expression and promoter activity of genes for isozymes of horseradish peroxidase. Plant Cell Physiol. 33:1143-1150.

Klibanov, A. M. and E. D. Morris. 1981. Horseradish peroxidase for the removal of carcinogenic aromatic amines from water. Enzyme Microb. Technol. 3:119-122.

Krel, H. W. 1991. Peroxidase: An important enzyme for diagnostic test kits, p. 470-478. In: J. Lobarzewski, H. Greppin, C. Pelel, and T. Gaspar (eds.). Biochemical, molecular, and physiological aspects of plant peroxidases. Imprimerie Natl., Geneva, Switzerland.

Lobarzewski, J. and R. van Huystee. 1982. Purification of a cationic peanut peroxidase by immunoaffinity chromatography. Plant Sci. Lett. 26:39-46.

Lotmani, B. and J. Rabier. 1988. Induction of two callus lines (Armoracia rusticana) and their peroxidase characterization. C.R. Acad. Sci. 307:215-220

Macek, T., T. Dobransky, R. Pospisilova, T. Vanek, and B. Kralova. 1993. Peroxidases from in vitro cultures of different plant species, p. 451-455. In: K. G. Welinder, S. K. Rasmussen, C. Penel and $\mathrm{H}$. Greppin (eds.). Plant peroxidases: biochemistry and physiology. Univ. Geneva Press,
Geneva, Switzerland.

Ohtsuru, M. and H. Kawatani. 1979. Studies of the myrosinase from Wasabia japonica: Purification and some properties of wasabi myrosinase. Agr. Biol. Chem. 43:2249-2255.

Oliver, J., R. Berlin, and B. Davis. 1984. Use of horseradish peroxidase and flourescent dextrans to study fluid pinocytosis in leukocytes. Meth. Enzymol. 108:336-347.

Parkinson, M., T. Cotter, and P.J. Dix. 1990. Peroxidase production by cell suspension and hairy root cultures of horseradish (Armoracia rusticana). Plant Sci. 66:271-277.

Peck, T.R., J.W. Courter, A.M. Rhodes, and W.M. Walker. 1969. Mineral composition of horseradish (Armoracia rusticana). Agron. J. 61:526-527.

Peive, Y., N. Ivanova, and N. Drobysheva. 1972. Nitrate-reducing activity of plant peroxidase (horseradish). Soviet Plant Physiol. 19:278284.

Reuveni, R.M., M. Shimoni, Z. Karchi, and J. Kue. 1992. Peroxidase activity as a biochemical marker for resistance of muskmelon (Cucumis melo) to Pseudoperonospora cubensis. Phytopathology 82:749-753.

Rhodes, A.M., J.W. Courter, and M.C. Churtleff. 1965. Identification of horseradish types. Illinois State Acad. Sci. 58:115-122.

Rhodes, A.M., S.G. Cramer, and J.W. Courter. 1969. Measurement and classification of genetic variability of horseradish. J. Amer. Soc. Hort. Sci. 94:98-102.

Roper, J.C., J. Dec, and J.M. Bollag. 1996. Biodegradation and bioremediation. Using minced horseradish roots for the treatment of polluted waters. J. Environ. Qual. 25:1242-1247.

Ryan, O., M.R. Smyth, and C.O. Fagain. 1994. Thermostabilized chemical derivatives of horseradish peroxidase. Enzyme Microb. Technol. 16:501-505.

SAS Institute. 1990. SAS/STAT user's guide. vers. 6.12, 4th ed. SAS Inst., Cary, N.C.

Tijssen, P. 1985. Properties and proportion of enzymes used in enzyme-immunoassays, p.173219. In: R. Burdon and P. Van Knippenberg (eds.). Laboratory techniques in biochemistry and molecular biology, vol.15. Elsevier, Amsterdam, The Netherlands. 